\title{
Analysis of Thermal Comfort SNI 03-6572 In Green Open Space Siring Tendean Banjarmasin-Indonesia
}

\author{
Akbar Rahman, Shoichi Kojima
}

\begin{abstract}
Save energy in building environment becomes a popular concept for architects. Energy saving is not only applied to the building, but also on the urban plan and urban design, because it is proven that: urban heat island and global warming increase the near surface ambient temperature in cities. Indonesia is one of the developing countries that continue to develop. Today, sustainable development is already a major issue in development. Cities in Indonesia have at least $30 \%$ of green open space. Banjarmasin is one of the cities in Indonesian. Based on the data, Banjarmasin has the green open space of at least $5.13 \%$ in the center of the city. The increase in green open space has begun by revitalizing the area around the river into open space. Based on the measurement results: The condition of open spaces that have lots of vegetation, better thermal conditions. Open space with trees has been able to reduce environmental thermal conditions.
\end{abstract}

Keywords - Green open space, thermal, SNI 03-6572

\section{INTRODUCTION}

\section{A. Background}

Global warming is the unusually rapid increase in Earth's average surface temperature over the past century, primarily due to the greenhouse gases released as people burn fossil fuels. The global average surface temperature rose 0.6 to $0.9^{\circ} \mathrm{C}$ between 1906 and 2005 , and the rate of temperature increase has nearly doubled in the last 50 years [1]. This condition triggers climate change. More uncertain-but possible-outcomes of an increase in global temperatures include increased risk of drought and increased intensity of storms, including tropical cyclones with higher wind speeds, a wetter Asian monsoon, and, possibly, more intense midlatitude storms [2].

Climate change has raised the awareness of the world to maintain sustainability, and prove the truth of the document "Our Common Future" in 1987 by The World Commission on Environmental and Development (WCED), an institution established by the United Nations (UN). This concept encourages a fundamental paradigm shift in environmental development. The focus of development of intra-generational equity in various development activities [3]. The paradigm is

\footnotetext{
Akbar Rahman, Saga University \& Lambung Mangkurat University Indonesia, arzhi_teks@yahoo.co.id

Shoichi Kojima, Saga University, Japan, email ID: shokjm@cc.sagau.ac.jp
}

the basis of the theories of sustainable development as the science of architecture. Sustainable development, which is capitalizing on the platform sustainability practices and innovations aimed at creating a sustainable built environment that reduces energy consumption, combats environmental degradation and creates a better environment for living through the sustaining pillars.

Reduced use of non-renewable energy sources has become an option in architectural design. Save energy in building environment becomes a popular concept for architects. Energy saving is not only applied to the building, but also on the urban plan and urban design, because it is proven that: urban heat island and global warming increase the near surface ambient temperature in cities [4]. The condition is influenced by the urban population, and the city as the center of activity. Increased urban surface temperature due to population activity, should get the solution so that the use of fossil energy can be reduced. One solution is the development of green open spaces in the city area. Green open space can reduce the surface temperature of the city area [5].

Indonesia is one of the developing countries that continue to develop. Today, sustainable development is already a major issue in development. Energy efficiency continues to be done by making government regulations. Indonesia already has regulation of regional development and the city: 1) Regulation of Spatial Planning [6] and 2) Guidelines for the Provision of Green Open Space in Urban Areas [7]. Both regulations are to support sustainable development. Cities in Indonesia have at least $30 \%$ of green open space.

\section{B. The Study Contex}

Banjarmasin is one of the cities in Indonesian, located at $3^{\circ} \mathrm{NL}$ to $114^{\circ} \mathrm{EL}$, and as the provincial capital of South Kalimantan. Banjarmasin city must follow the regulation about green open space $30 \%$. Banjarmasin is divided into 5 districts, namely: Banjarmasin Barat, Banjarmasin Utara, Banjarmasin Selatan, Banjarmasin Tengah and Banjarmasin Timur. Each area of the city must have $30 \%$ green open space, but this has not been achieved. Based on the data, Banjarmasin Tengah has the green open space of at least 5.13\%. Though Banjarmasin Tengah is the center of Banjarmasin city, Table I. Thus, causing the city government to increase green open space, especially in the central area of the city. The increase in green open space has begun by revitalizing the area around the river into open space, namely in Siring Tendean. 
TABLE I

LAND OF COVERED IN BANJARMASIN [8]

\begin{tabular}{lcc}
\hline \multicolumn{1}{c}{ Districts } & Covered building (\%) & Green open space (\%) \\
\hline \hline Banjarmasin Barat & 76,24 & 23,76 \\
Banjarmasin Utara & 62,3 & 37,7 \\
Banjarmasin Selatan & 5,34 & 94,66 \\
Banjarmasin Tengah & 94,87 & $\mathbf{5 , 1 3}$ \\
Banjarmasin Timur & 10,22 & 89,78 \\
\hline
\end{tabular}

Siring Tendean as a public space, a place to meet townspeople. As a public space, these places should provide comfort for visitors. Thermal comfort during the day need to be considered. The direct sunlight barrier is required in open spaces, building or house. The building is a protector of direct sunlight during the day and is a key strategy in achieving thermal comfort in hot conditions [9]. As a protector of direct sunlight, can reduce the level of heat in open space (outdoor) and houses (indoor). Thermal comfort is influenced by many factors such as: activity, clothing and the environment [10]. This research the influence of environment on thermal comfort. The Indonesian Standardization Board (BSN) issued a national standard ventilation system and energy conservation [11], [12]. The thermal comfort standard required to help the designer to provide a comfortable building [13].

The Indonesian Standardization Board (BSN) issued a national standard ventilation system and energy conservation [11], [12]. Indonesian National Standard for standard ventilation systems should pay attention to thermal comfort. Indonesian National Standard (SNI) for the standard ventilation system must pay attention to thermal comfort. In this study using thermal comfort SNI 03-6572 with the thermal comfort standard is effective temperature (ET) 20.5oC$27.10 \mathrm{C}$. Determination of the comfort zone is not only seen from a dry bulb temperature, but also pay attention to wet bulb temperature, humidity and wind [14].

\section{RESEARCH METHODS}

\section{A. Description of Location and Places of Research}

Banjarmasin city is the capital of South Kalimantan province, as well as the largest and the most populous city in Kalimantan. Banjarmasin city located on the $3^{\circ} 15^{\prime}$ to $3^{\circ} 22^{\prime}$ $\mathrm{SL}$ and $114^{\circ} 32^{\prime} \mathrm{EL}$, ground altitude is at $0.16 \mathrm{~m}$ below sea level and almost the whole area is flooded at high tide. It is located in the east of the river of the Barito and cleaved by the river of Martapura tipped in Meratus Mountain. The river has become a major point of community activities since the first [10]. The rivers that cut through the city, pursued as a magnet economy, especially tourism [11].

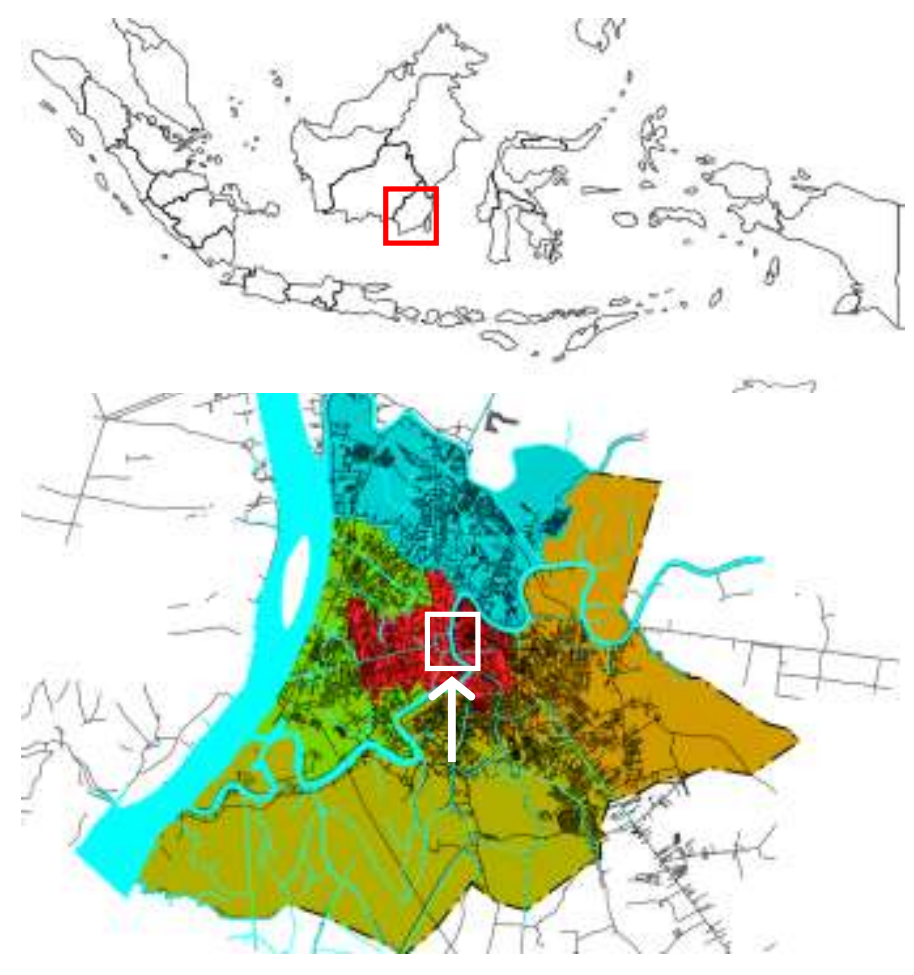

Fig. 1 Research location in Indonesia-Banjarmasin

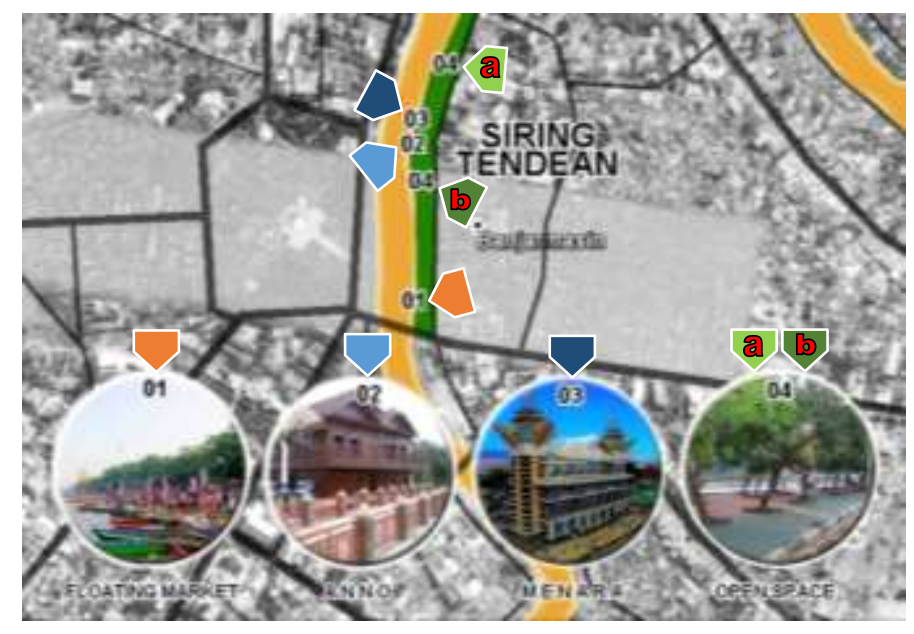

Fig. 2 Research point in the Siring Tendean Banjarmasin

\section{B. Research Variables and Measurement Procedure}

The purpose of this study was to determine the thermal comfort in public space situated around the river in the city of Banjarmasin. For that reason, the independent variable research is a green open space around the river, while the dependent variable is the thermal condition. Temperature, humidity, air velocity and solar radiation are used to determine the condition of thermal comfort in green open space Siring Tendean. And the control variables are comfort zone with psychometric charts, diagrams effective temperature and standards of SNI 03-6572. Field measurements conducted in three locations from 25th - 27th September 2016 in Siring 
Tendean. Scheme of research and measurement period and instruments is shown in Table II and Figure 3.

TABLE II

MEASUREMENT PERIOD AND INSTRUMENTS

\begin{tabular}{ll}
\hline Measurement items & Temperature, humidity, and air velocity \\
\hline Measuring instruments & $\begin{array}{l}\text { Data logger-4HC for temperature and humidity } \\
\text { Extech AN100 for air velocity }\end{array}$ \\
\hline $\begin{array}{l}\text { Calculate of wet bulb } \\
\text { temperature }\end{array}$ & Psychometric charts \\
\hline $\begin{array}{l}\text { Calculate of effective } \\
\text { temperature }\end{array}$ & Diagrams effective temperature \\
\hline Field measurement & $\begin{array}{l}\text { 25th - 27th September 2016 } \\
\text { Time: 6:00 am to 05:00 am (every hour/24 } \\
\text { hours) }\end{array}$ \\
\hline $\begin{array}{l}\text { High measuring } \\
\text { instruments from the } \\
\text { ground/floor }\end{array}$ & $150 \mathrm{~cm}$ \\
\hline
\end{tabular}

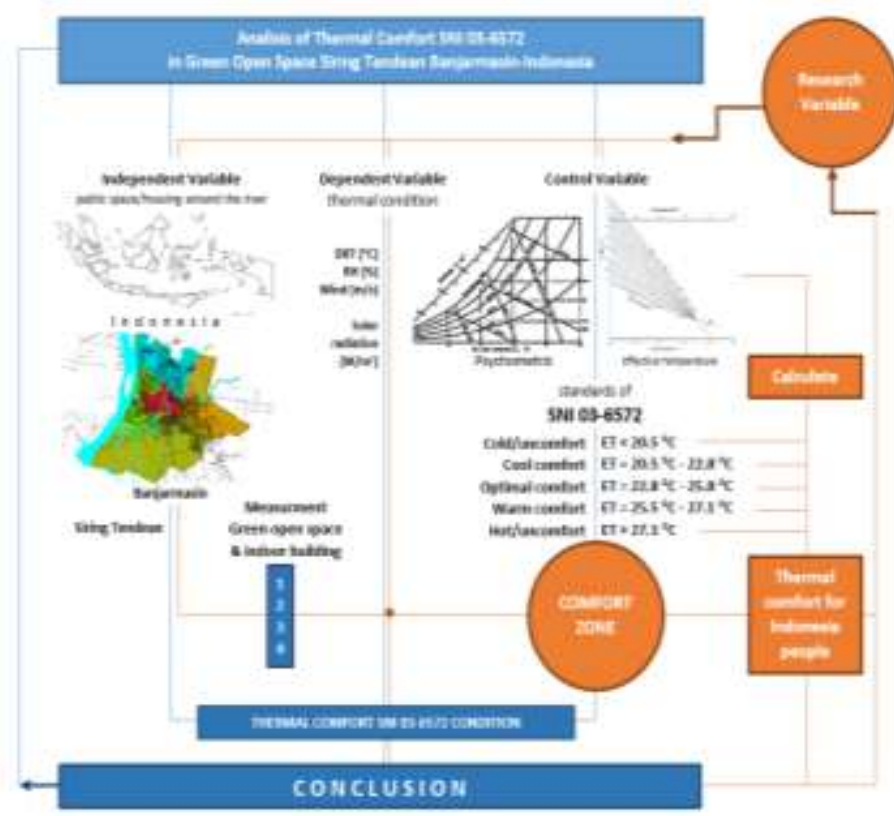

Fig. 3 Research process

\section{RESULT AND DISCUSSION}

\section{A. Thermal Comfort for Indonesia People}

Thermal comfort is that condition of mind which expresses satisfaction with the thermal environment and is assessed by subjective evaluation. Because there are large variations, both physiologically and psychologically, from person to person, it is difficult to satisfy everyone in a space. The environmental conditions required for comfort are not the same for everyone. Sensation of thermal: a conscious feeling commonly graded into the categories, cold, cool, slightly cool, neutral, slightly warm, warm, and hot; it requires subjective evaluation [15].

The Government of Indonesia, through the Department of Kementrian PUPR has issued thermal comfort standards of space in buildings. The National Standardization Agency of Indonesia (BSN) issued a national standard ventilation system and energy conservation [11], [12]. This standard is intended as a guide for planning, building and building management. Aims to gain comfort and safety for guests or residents.
Indonesian National Standard for standard ventilation systems should pay attention to thermal comfort. Indonesian National Standard (SNI) for the standard ventilation system must pay attention to thermal comfort. The standard is SNI 03-6572-2001 with effective temperature (ET) 20.5OC to 27.1OC and SNI 6390-2011 with operative temperature (Top) 24OC-27OC. In this study using thermal comfort SNI 036572, because it uses an effective temperature that has many variables: temperature, humidity and air velocity. Determination of the comfort zone is not only seen from a dry bulb temperature, but also pay attention to humidity and wind [14]. The thermal comfort index at an effective temperature for humid tropics can be divided into [11]:

- Cool comfort, between the effective temperature of $20.5^{\circ} \mathrm{C} \sim 22.8^{\mathrm{O}} \mathrm{C}$.

- Optimal comfort, between the effective temperature of $22.8^{\mathrm{O}} \mathrm{C} \sim 25.8^{\mathrm{O}} \mathrm{C}$.

- Warm comfort, between the effective temperature of $25.8^{\circ} \mathrm{C} \sim 27.1^{\circ} \mathrm{C}$.

Thermal comfort zone for Indonesian people, when viewed on the psychometric chart will be like the Figure 4:

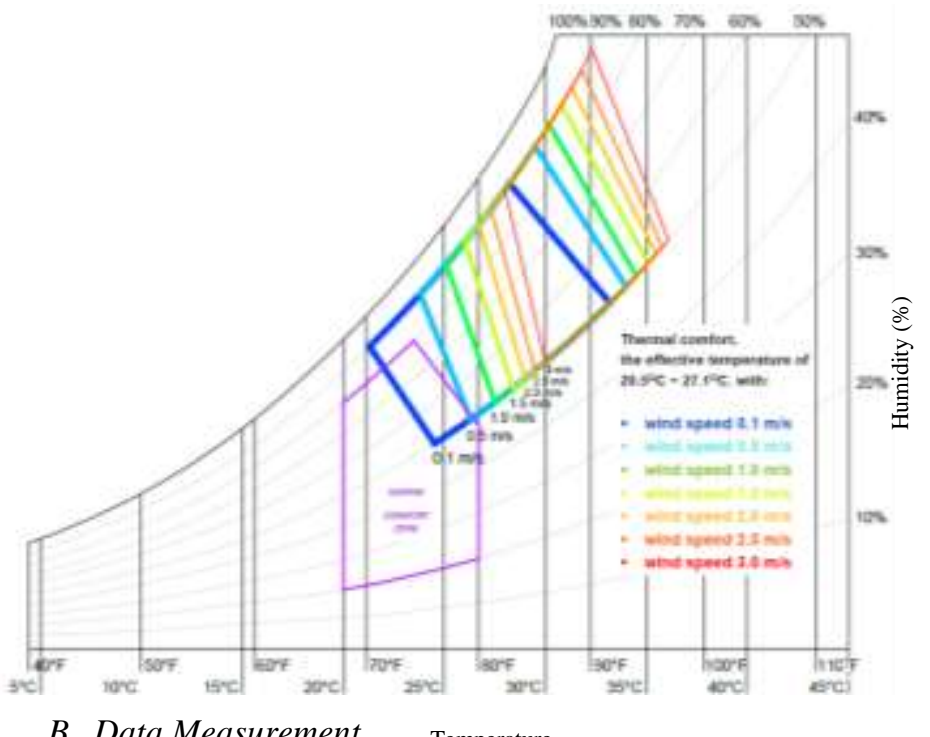

\section{B. Data Measurement Temperature}

Based on the results of measurement on site research, humidity, temperature, wind speed and solar radiation can be seen in Figure 5. At the time of measurement condition of clear skies, it can be seen from the solar radiation. The value of solar radiation measurement for 3 days tend to be the same, with a maximum value of $1,072 \mathrm{~W} / \mathrm{m} 2$ at $1 \mathrm{pm}$. Wind Conditions an average of $2 \mathrm{~m} / \mathrm{s}$, and the faster in the afternoon. Wind speed is relatively high because of the location of the measurement is around the river are open free to air flow. Air humidity in the green open space, is always higher than the humidity of the building indoor. This also happens in the open spaces around the floating market a low vegetation. The air was humid highs occur in the morning. The condition of the air temperature in the green open space is always lower than the temperature of the building. During the day the temperature of 
the open space around the floating market is quite high, due to the lack of a tree as a patron of the solar radiation. Based on the results of the measurements, thermal conditions in green open space are relatively better than the thermal buildings and open spaces without vegetation.

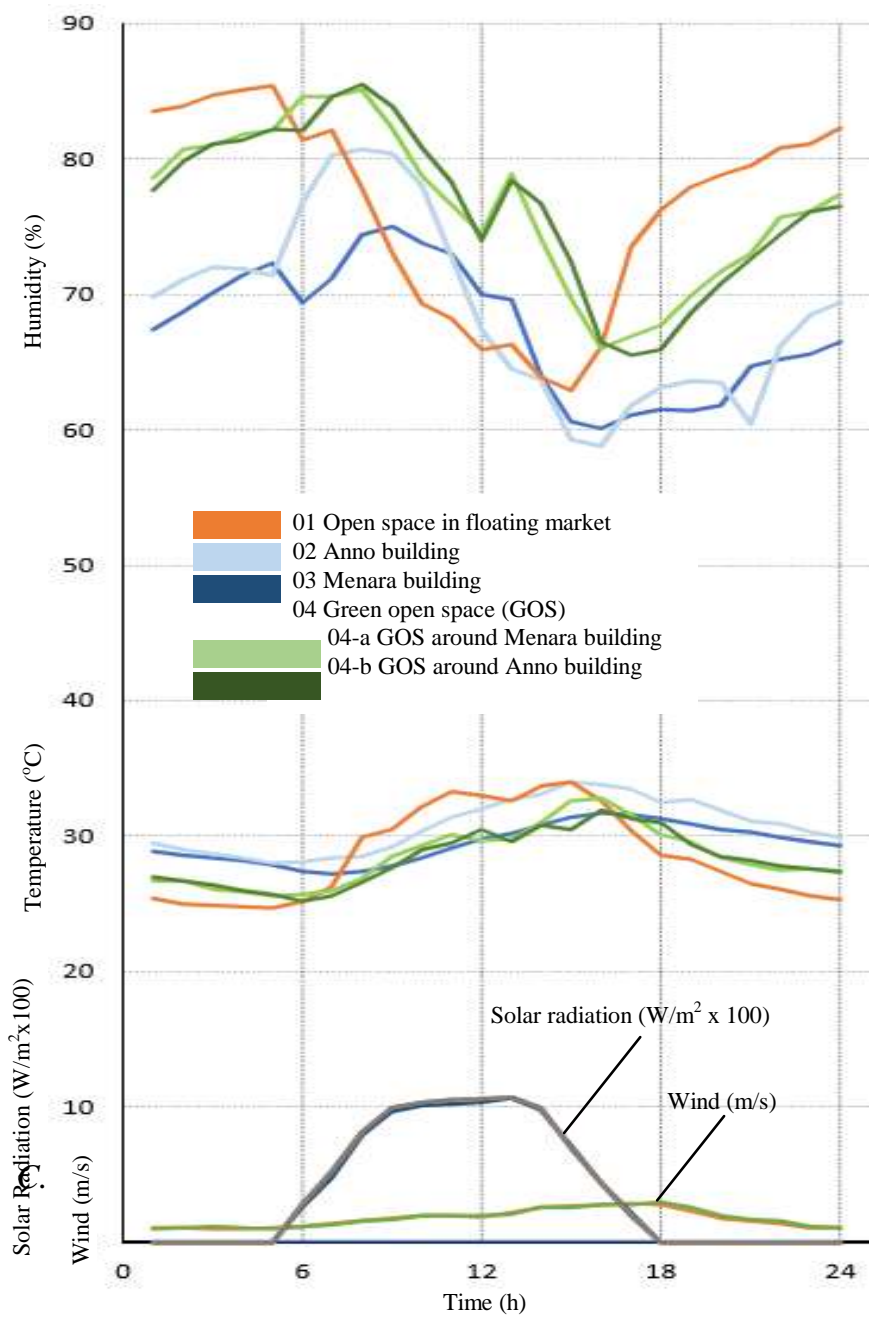

Thermal comfort conditions in the Menara building are more convenient than Anno building. The effective temperature of the Menara building is always in the thermal comfort zone SNI 03-6572, while Anno building in the afternoon until the evening out of the comfort zone. Although the Menara building is always in a comfort zone, but during the day felt warm thermal conditions, because of the high solar radiation affects the temperature and humidity. Conditions of thermal comfort in buildings are better at night than during the day. And optimal thermal comfort conditions in the Menara building and Anno building occurs at night. See
Figure 6.

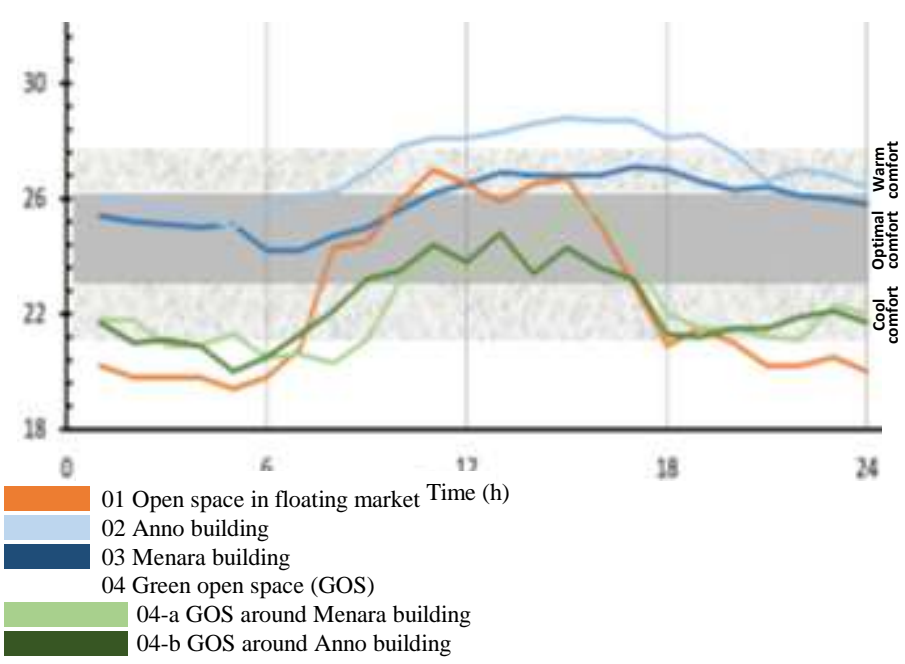

Fig. 6 Thermal comfort SNI 03-6572 conditions in Siring Tendean

Thermal comfort conditions in outer space: a green open space is more comfortable than buildings. Effective temperature of green open space is always in the thermal comfort zone of SNI-03 6572, with thermal comfort conditions to be optimally comfortable. While the slightly open space of vegetation during the day tends to warm comfort, and at night the conditions are not comfortable. This is due to low air temperature and high humidity around the river, can cause cold. The presence of trees in green open spaces can control in a comfort zone and can also affect the thermal conditions of the surrounding environment. See Figure 6. So, if sorted thermal comfort conditions in Siring Tendean from more convenient conditions are: green open space, open space around the floating market, Menara building and Anno building. In macro conditions, thermal green open space in Siring Tendean is comfortable.

The green open space in Siring Tendean has lowered the average effective temperature of the environment and buildings. The average effective temperature of residential buildings in the city of Banjarmasin is around 27.220C, with conditions not being around green open spaces [16]. The condition is $0.630 \mathrm{OC}$ higher than the average effective temperature of buildings around green open space. From these data, the average effective temperature of residential buildings in Banjarmasin is still outside the comfort zone of SNI 036572, while the thermal measurement results of buildings in green open space, the average effective temperature is 26,49OC and enter the comfort zone of SNI 03-6572, with a comfortable warm category. This proves that green open space has been able to lower the average effective temperature in buildings around $0.730 \mathrm{C}$.

The average effective temperature of green open space is lower than the open space around the floating market. The average effective temperature of green open space is $22.260 \mathrm{C}$ while the open space around the floating market is $22.47 \mathrm{OC}$, with a difference of $0.210 \mathrm{C}$. The average effective temperature of green open space and open space around the 
floating market enters the comfort zone of SNI $03-6572$, with a comfortable cool category, see figure 7 . The condition of open spaces that have lots of vegetation, better thermal conditions. Open space with trees has been able to reduce environmental thermal conditions.

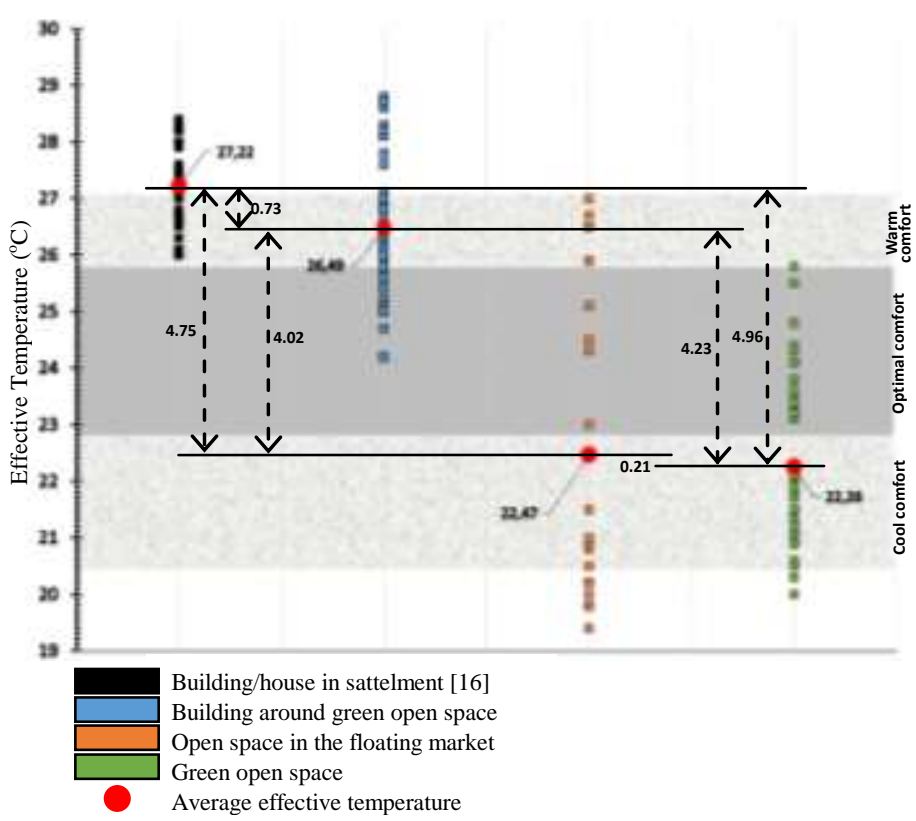

Fig. 7 Comparison thermal comfort SNI 03-6572 condition in Siring Tendean and building/house in Banjarmasin

\section{CONCLUSION}

Indonesia already has regulation of regional development and the city. Both regulations are to support sustainable development. Cities in Indonesia have at least 30\% of green open space. Banjarmasin city must follow the regulation about green open space $30 \%$. Based on the data, Banjarmasin has the green open space of at least $5.13 \%$ in the center of the city. The increase in green open space has begun by revitalizing the area around the river into open space, namely in Siring Tendean.

As a public space, these places should provide comfort for visitors. Thermal comfort during the day need to be considered. The direct sunlight barrier is required in open spaces, building or house. This research the influence of environment on thermal comfort. The Government of Indonesia, through the Department of Kementrian PUPR has issued thermal comfort standards of space in buildings.

Conditions of thermal comfort in buildings are better at night than during the day. And optimal thermal comfort conditions in the Menara building and Anno building occurs at night. The green open space in Siring Tendean has lowered the average effective temperature of the environment and buildings. This proves that green open space has been able to lower the average effective temperature in buildings. The condition of open spaces that have lots of vegetation, better thermal conditions. Open space with trees has been able to reduce environmental thermal conditions.

\section{REFERENCES}

[1] 'Global Warming', NASA, accessed on June 5th, 2017, <https://earthobservatory.nasa.gov/Features /GlobalWarming>.

[2] 'The Impact of Climate Change on Natural Disasters', accessed on June 5th, 2017, https://earthobservatory.nasa.gov/Features/RisingCost/rising _cost5.php>.

[3] 'Report of the World Commission on Environment and Development: Our Common Future', Strategic Imperatives, accessed on June 6th, 2017, <http://www.ask-force.org/web/Sustainability/Brundtland-OurCommon-Future-1987-2008.pdf $>$.

[4] Santamouris, M, 2014, 'On the energy impact of urban heat island and global warming on buildings', Energy and Buildings, Vol.34. Pp. 100113.

[5] Rahman, A, 2010, 'The Different Air Temperature in The Shadowed and Unshadowed Condition, International Conference on Sustainable Environmental Architecture (SENVAR), ITS, Surabaya.

[6] 'Undang-undang tentang Penataan Ruang', BNPB, accessed on Juni 7th, 2017, <https://www.bnpb.go.id/uploads/migration/pubs/2.pdf>.

[7] 'Peraturan Menteri PU No. 05/PRT/M/2008 tentang Pedoman Penyediaan Ruang Terbuka Hijau di Kawasan Perkotaan', Kementrian $P U, \quad$ accessed on June 7th, 2017, <http://www.penataanruang.com/pedoman-ruang-terbuka-hijau.html>.

[8] Pujirahayu, Yuni, 2010, Identifikasi Karakteristik Ruang Terbuka Hijau pada Kota Dataran Rendah di Indonesia. Departemen Arsitektur Lanskap-IPB, Bogor.

[9] Mom, C.P.P., Wiesebron J.A., Courtice, R., Kip, C.J., 1947, The application of the effective temperature scheme to the comfort zone in the Netherlands Indies (Indonesia), Chron. Nat., 103, 19-31.

[10] Fanger, P, O, 1970, 'Analysis and applications in environmental engineering', Thermal comfort. Danish Technical Press, Pp. 244.

[11] Badan Standardisasi Nasional (BSN). Standar Nasional Indonesia (Indonesian National Standardization)-SNI 03-6572:2001 Tata Cara Perancangan Sistem Ventilasi dan Pengkondisian Udara pada Bangunan Gedung, BSN, Jakarta, Indonesia. 2001.

[12] Badan Standardisasi Nasional (BSN). Standar Nasional Indonesia (Indonesian National Standardization)-SNI 6390:2011 Konservasi Energi Sistem Tata Udara Bangunan Gedung, BSN, Jakarta, Indonesia. 2011.

[13] Nicol, J.F., Humphreys, M.A., 2002, 'Adaptive thermal comfort and sustainable thermal standards for buildings', Energy and Buildings, Vol. 34, Pp. 563-572.

[14] Rahman, A, Kojima, S, 2017, 'Analysis of thermal comfort SNI-6390 in the Lanting (floating house)'. International Proceedings of Chemical, Biological and Environmental Engineering, Vol. 100.

[15] ASHRAE Standard 55 P: Thermal Environmental Conditions for Human Occupancy, 2003.

[16] Rahman, Akbar, 2016, Memahami Pola Pembayangan pada 128 Variant Overstek. Unlam Press. Banjarmasin.

About Author (s):

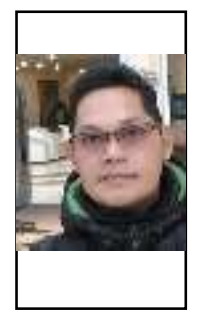

Akbar Rahman : He is graduated of Architecture at the University of Lambung Mangkurat, Master of Architecture at the University of Diponegoro, with specialization Urban Design in the Tropics. Is currently completing a doctoral course in Department of Civil Engineering and Architecture at Saga University, Japan. And he is a member of Indonesian Architects Association (IAI)

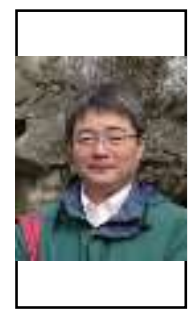

Shoichi Kojima : He is a Professor, Department of Civil Engineering and Architecture at Saga University, Japan. He received $\mathrm{PhD}$ at Kyushu University, Japan. $\mathrm{He}$ is a member of the Architectural Institute of Japan (AIJ), and the American Society of Heating, Refrigerating and AirConditioning Engineers (ASHRAE). His research interests include indoor thermal environment and 